\title{
Earthquakes Effect on the Behavior of Multi-Story RC Building Using Non-Linear Dynamic Analysis
}

\author{
${ }^{1}$ M Nadir Olabi, ${ }^{2}$ Osman Kirtel and ${ }^{* 1,2}$ Naci Caglar \\ ${ }^{1}$ Sakarya University, Engineering Faculty, Department of Civil Engineering, 54187 Sakarya, Turkey \\ ${ }^{2}$ Sakarya University of Applied Sciences, Faculty of Technology, Department of Civil Engineering, Sakarya, Turkey
}

\begin{abstract}
One of the buildings that were designed depending on the old Syrian Code is selected and modeled using SAP2000 by taking its non-linear properties to be checked under dynamical loading. Three earthquake records are taken and applied to the model as Time History loading cases. The dynamical displacement of the top roof of the building and the hysterical diagrams of the relation between base shear and roof displacement is compared and discussed. Asymmetry of shear walls and cores is responsible of the differences in responses of building elements, and insufficient nonlinear modeling of shear walls prevents from finding the real capacity of the system, although comparing pushover curves with hysteric loops from the applied ground motion excitations shows that the building is capable, depending on its old design, to withstand various types of extreme ground motions and earthquakes.
\end{abstract}

Key words: RC building, earthquake effects, time history, nonlinear, dynamic, SAP2000

\section{Introduction}

Earthquake is one of the most dangers types of hazards that can cause the greatest damages to humanity among all type of natural phenomena. Since earthquake forces are unpredictable and random in nature, proper analysis of the structures must be ensured to withstand such loads. The recent developments in the performance based design have introduced new tools to structural engineering field like the non-linear static or pushover analysis and the non-linear dynamic or time history analysis. These types of analysis are replacing the conventional analysis procedures, because of their effectiveness in assessing and predicting behaviors of structural systems under effect of lateral loading and earthquakes specifically.

Old Syrian Standards which also based on conventional American Codes like UBC97 and others, did not take into account most of the non-linear and dynamic behaviors of structures. In addition, most of the buildings which were designed based on these codes over estimated these effects to from a safety point of view, for that reasons, it is very important to reevaluate these building depending on the new analyzing methods and test their real behaviors under earthquakes and dynamical types of loadings $[1,2]$.

\footnotetext{
* Corresponding author: Address: Faculty of Engineering, Department of Civil Engineering Sakarya University, 54187, Sakarya TURKEY. E-mail address: caglar@sakarya.edu.tr, Phone: +902642955752
} 
Lot of nowadays available computer software packages can perform non-linear analysis easily with a lot of options; one of those is the structural analyzing program SAP2000 [3] which can perform static and dynamic, linear and nonlinear analysis of structural systems. To perform nonliner analysis in SAP2000, users can create and apply hinge properties and determine the location of where the hinges will be created. Moreover, SAP2000 is fully equipped with types of standards and codes that could be used to test and evaluate the structure response under ground motion excitations.

\section{System Description}

An existing building designed and built according to older standards is chosen for the purpose of this study. The building services as Hayat Hospital in Damascus, Doma Province, and consists of the system shown in Figure 1. The building in study is nine stories with $3.5 \mathrm{~m}$ of floor height. The loading bearing structural system consists of a mix of frames and shear walls, the distribution of the shear walls could be seen in Figure 1. Shear walls have a fixed thickness of $25 \mathrm{~cm}$ for all levels; columns on the other hand have a changing cross section every three stories. The cross sections and reinforcement arrangements of the columns could be found on Table 2. Beams have the same cross section for the whole building as $250 \times 450 \mathrm{~mm}$ except near the elevators and in middle of stairs there is a smaller beam with 250x300 mm (Table 1). Floor slabs are hollow block slabs with a total thickness of $300 \mathrm{~mm}$ and concrete slab thickness of $6 \mathrm{~mm}$. $200 \mathrm{~mm}$ slab is used for the stairs and block infill walls have $200 \mathrm{~mm}$ thickness. The building was designed with distributed loads of $2.5 \mathrm{kN} / \mathrm{m}^{2}$ dead loads and $4 \mathrm{kN} / \mathrm{m}^{2}$ live loads. The concrete has a design compressive strength $\left(\mathrm{f}_{\mathrm{co}}\right)$ of $25 \mathrm{MPa}$, and the reinforcement steel used for longitudinal bars have yield strength $\left(f_{y s}\right)$ of $400 \mathrm{MPa}$, and for transverse reinforcement $\left(f_{y s t}\right)$ is $240 \mathrm{MPa}$. Although, it is recommended to use the actual values of material properties depending on site tests for this kind of studies, but since lack of this kind of information the design values are used in this work. 


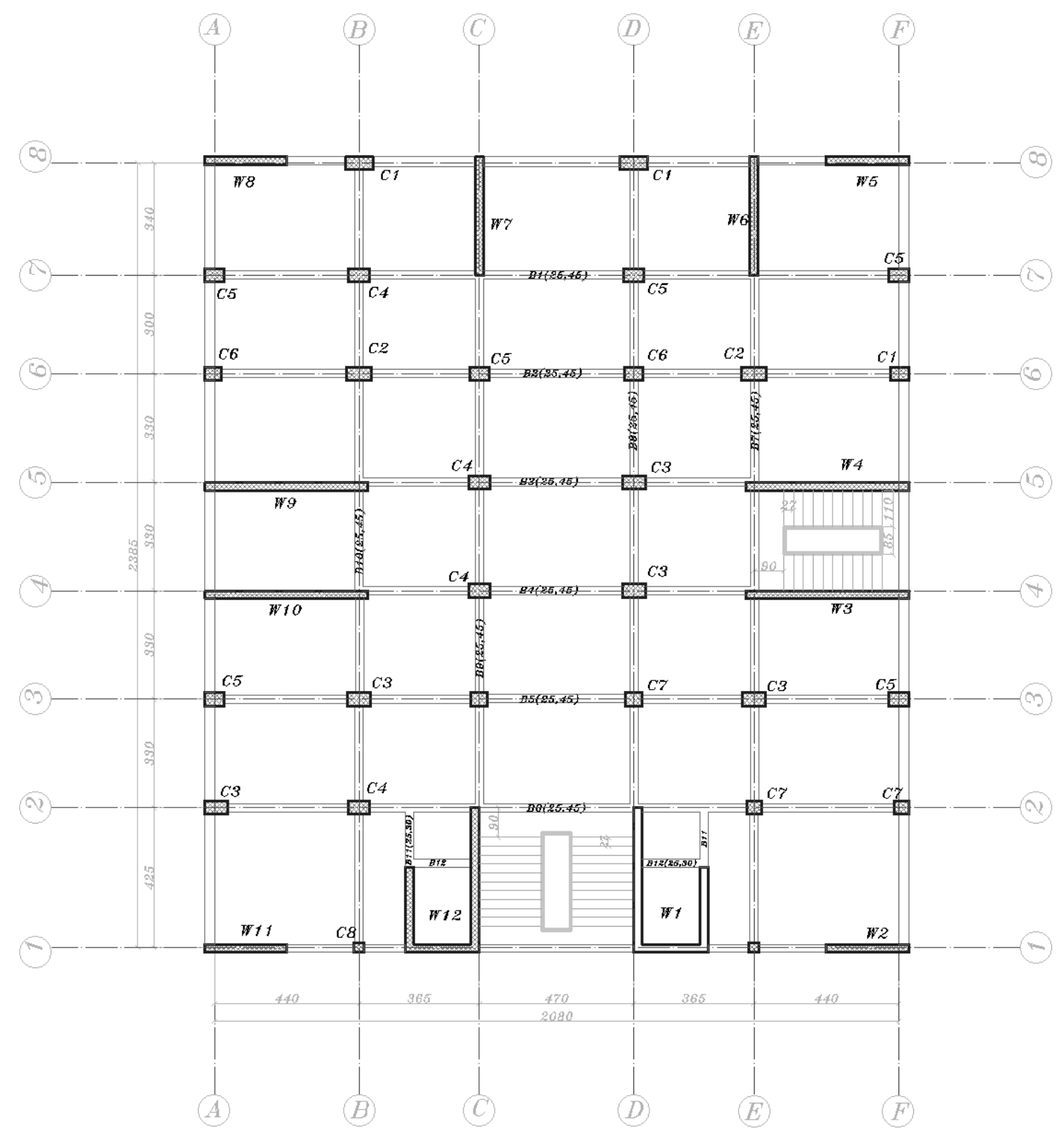

Figure 1 Axes plan for the chosen RC building

Table 1 Dimensions and reinforcement arrangements for beams

\begin{tabular}{cccc}
\hline Beam Name & $\begin{array}{c}\text { Dimensions } \\
(\mathbf{m m})\end{array}$ & $\begin{array}{c}\text { Longitudinal Steel } \\
(\mathbf{m m})\end{array}$ & $\begin{array}{c}\text { Transverse Steel } \\
(\mathbf{m m})\end{array}$ \\
\hline Beam25x30 & $250 \times 300 \mathrm{~mm}$ & $2 \phi 14$ & $\phi 8 / 250$ \\
\hline Beam25x45 & $250 \times 450 \mathrm{~mm}$ & $5 \phi 16$ & $\phi 8 / 250$ \\
\hline
\end{tabular}

Table 1 Dimensions and reinforcement arrangements for columns 


\begin{tabular}{|c|c|c|c|}
\hline & Floors $1-2-3$ & Floors 4-5-6 & Floors $7-8-9$ \\
\hline $\begin{array}{l}\text { Column } \\
\text { type }\end{array}$ & $\begin{array}{c}\text { Dimensions }(\mathrm{mm}) \\
\text { Longitudinal Steel }(\mathrm{mm}) \\
\text { Transverse Steel }(\mathrm{mm})\end{array}$ & $\begin{array}{c}\text { Dimensions }(\mathrm{mm}) \\
\text { Longitudinal Steel }(\mathrm{mm}) \\
\text { Transverse Steel }(\mathrm{mm})\end{array}$ & $\begin{array}{c}\text { Dimensions }(\mathrm{mm}) \\
\text { Longitudinal Steel }(\mathrm{mm}) \\
\text { Transverse Steel }(\mathrm{mm})\end{array}$ \\
\hline C1 & $\begin{array}{c}400 \times 850 \\
20 \phi 18 \\
\phi 10 / 300\end{array}$ & $\begin{array}{c}400 \times 800 \\
18 \phi 18 \\
\phi 10 / 300\end{array}$ & $\begin{array}{c}400 \times 750 \\
18 \phi 18 \\
\phi 8 / 250\end{array}$ \\
\hline C2 & $\begin{array}{c}400 \times 750 \\
18 \phi 18 \\
\phi 8 / 250 \\
\end{array}$ & $\begin{array}{c}400 \times 700 \\
16 \phi 18 \\
\phi 8 / 250 \\
\end{array}$ & $\begin{array}{c}400 \times 650 \\
16 \phi 18 \\
\phi 8 / 250 \\
\end{array}$ \\
\hline $\mathrm{C3}$ & $\begin{array}{c}400 \times 700 \\
16 \phi 18 \\
\phi 8 / 250\end{array}$ & $\begin{array}{c}400 \times 650 \\
16 \phi 18 \\
\phi 8 / 250\end{array}$ & $\begin{array}{c}400 \times 600 \\
14 \phi 18 \\
\phi 8 / 250\end{array}$ \\
\hline C4 & $\begin{array}{c}400 \times 650 \\
16 \phi 18 \\
\phi 8 / 250 \\
\end{array}$ & $\begin{array}{c}400 \times 600 \\
14 \phi 18 \\
\phi 8 / 250 \\
\end{array}$ & $\begin{array}{c}400 \times 550 \\
14 \phi 18 \\
\phi 8 / 250 \\
\end{array}$ \\
\hline C5 & $\begin{array}{c}400 \times 600 \\
14 \phi 18 \\
\phi 8 / 250\end{array}$ & $\begin{array}{c}400 \times 550 \\
14 \phi 18 \\
\phi 8 / 250\end{array}$ & $\begin{array}{c}400 \times 500 \\
12 \phi 18 \\
\phi 8 / 250\end{array}$ \\
\hline C6 & $\begin{array}{c}400 \times 550 \\
14 \phi 18 \\
\phi 6 / 200 \\
\end{array}$ & \multicolumn{2}{|c|}{$\begin{array}{c}400 \times 500 \\
12 \phi 18 \\
\phi 6 / 200\end{array}$} \\
\hline C7 & & $\begin{array}{c}400 \times 500 \\
12 \phi 18 \\
\phi 6 / 200 \\
\end{array}$ & \\
\hline C8 & & $\begin{array}{c}300 \times 300 \\
6 \phi 18 \\
\phi 6 / 200\end{array}$ & \\
\hline
\end{tabular}

\section{Finite Element Model}

The chosen system was modeled using finite element computer program SAP2000 [3] (Figure 2). Thin-Shell element with $25 \mathrm{~cm}$ thickness was selected to model shear walls. Moreover, slabs were modeled using a null plate element just for holding the distributed loads and convey them to the beams, where floor slabs were assigned with one-way directional loading to emulate the loading type of hollow block slabs, while stair slabs with two-way loading. Slabs self-weight was calculated and added to dead loads. All the points in the same level were constrained to a rigid diaphragm. On the other hand, frame element was selected to model the columns and beams and the complete cross section details were supplied to the program with the exact reinforcement arrangements for the purpose of the non-linear analysis. Also, frame joints are modeled with rigid offsets to simulate the rigidity inside column-beam joints. Intersectional block walls loads were applied over the corresponding beams as dead loads. Mander's [4] nonlinear concrete model was used and assigned to the unconfined and confined concrete materials (Figure 3), and mass source was set to be taken from all dead loads and $30 \%$ from live loads. 


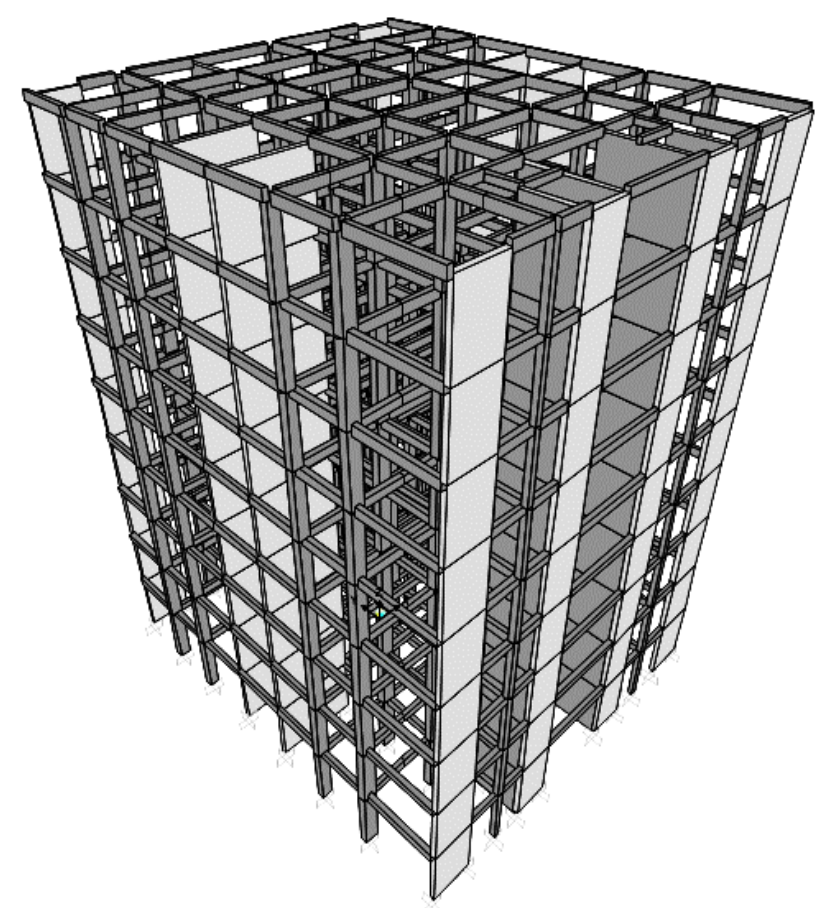

Figure 2 Finite element model of the system

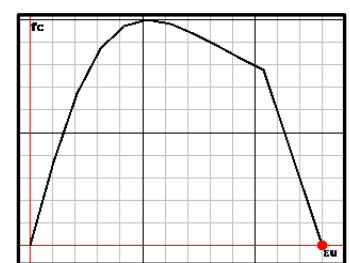

Unconfined Concrete

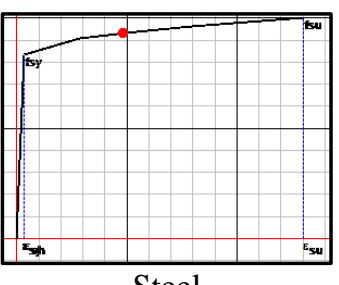

Steel

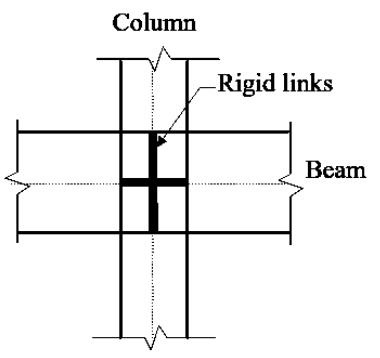

Figure 3 SAP200 modeling details

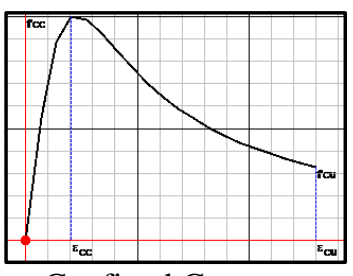

Confined Concrete

Material models used in the modeling

Rigid offsets in joints

Plastic hinges were defined and applied to both ends of each frame elements to simulate the sections nonlinearity in the structure. Moment M3 hinge type was assigned to beams, and the effective moment yield for beams is $148.5 \mathrm{kN}$.m as seen from the sectional analysis performed using XTRACT [5] program (Figure 4). On the other hand, column's plastic hinge type was chosen to be Fiber P-M2-M3 type, since it has more natural approach in simulations than the other types of hinge models available in the program, according to SAP2000 manual. In addition, this type could consider interaction, changing moment-rotation curve and plastic axial strain automatically [3].

A modal analysis was carried out using the developed FEM model of the building. The first three modal shapes with their corresponding periods for the 3D model could be found on Figure 5 . However, as seen in the figure and also from Table 3, the main mode is the one in Y direction according to the mass participating ratios of the different modes, and the other two modes are compound of $\mathrm{X}$ direction and rotation movements, which will affect the roof joints displacements in $\mathrm{X}$ direction. 


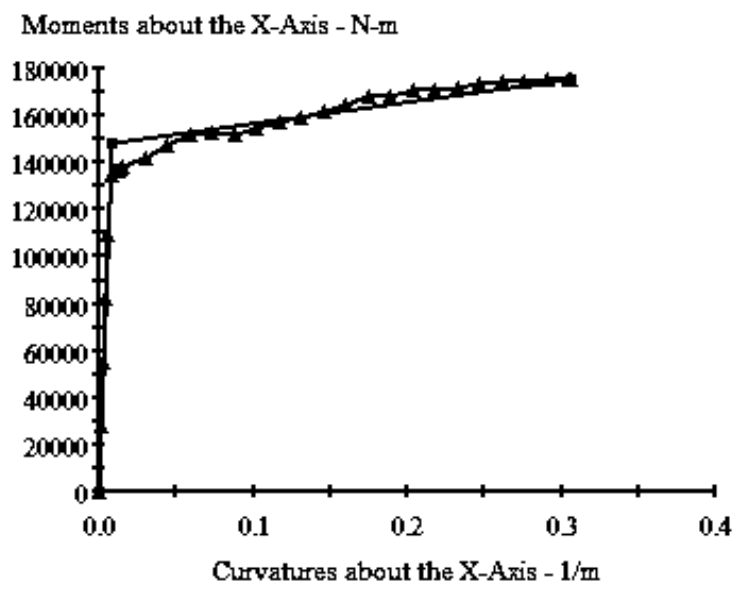

Figure 4 Curvature-Moment Relation and Idealization for Beams using XTRACT [5]

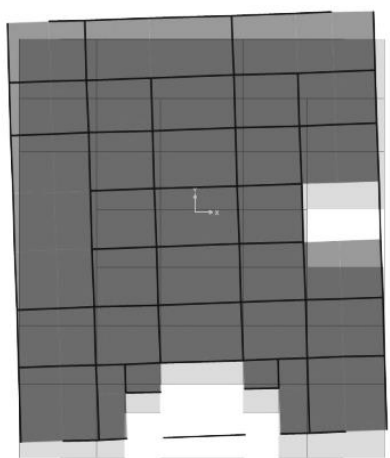

Mode 1

in $\mathrm{Y}$ Dir. $\mathrm{T}=1.118 \mathrm{~s}$
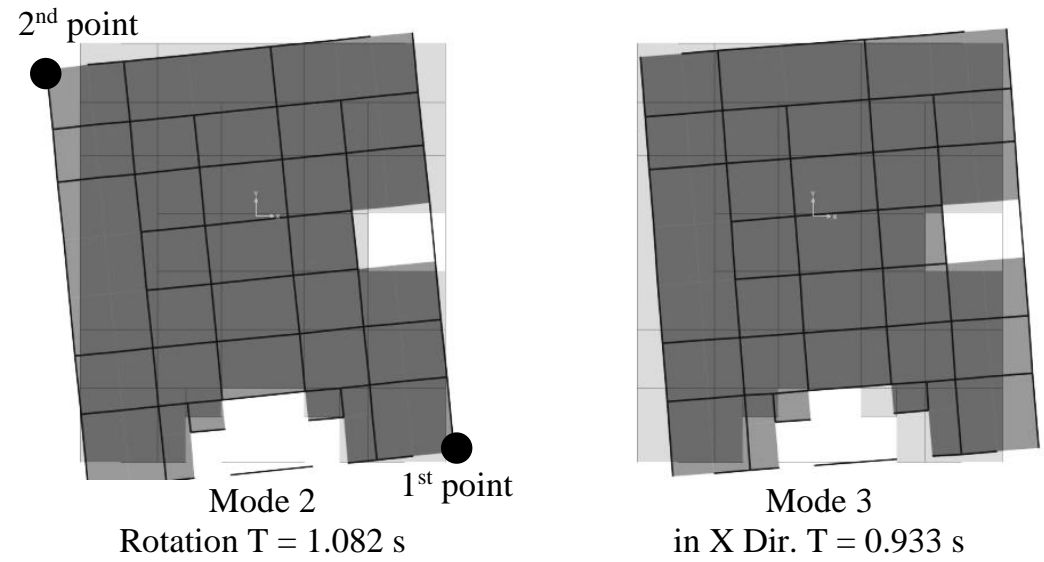

Mode 3

in $\mathrm{X}$ Dir. $\mathrm{T}=0.933 \mathrm{~s}$

Figure 5 Modal Shapes and Periods

Table 3 Modal Participation Mass Ratios

\begin{tabular}{ccccc}
\hline & $\begin{array}{c}\text { Period } \\
(\mathbf{s})\end{array}$ & $\begin{array}{c}\mathbf{U x} \\
(\mathbf{\%})\end{array}$ & $\begin{array}{c}\mathbf{U y} \\
(\boldsymbol{\%})\end{array}$ & $\begin{array}{c}\mathbf{R z} \\
(\boldsymbol{\%})\end{array}$ \\
\hline Mode 1 & 1.118 & 0 & 70.27 & 0.09 \\
\hline Mode 2 & 1.082 & 22.10 & 0.03 & 50.20 \\
\hline Mode 3 & 0.933 & 47.93 & 0.05 & 21.91 \\
\hline
\end{tabular}

\section{Earthquakes and Ground Motions Records}

As seen from Table 4, three different earthquakes records were chosen to perform the non-linear dynamic analysis on the selected building. The three records were selected to be from different parts of the world, Turkey, USA and Chile and with various magnitudes and time series styles (Figure 6). Raw time series records were used from famous databases, like PEER [6] and AFAD 
[7], and the records were corrected and scaled [8] according to the Turkish Standards [2] to fit a response spectrum in the first earthquake zone $(\mathrm{A} 0=0.4)$ with soil type Z1. Using SAP2000 a time history analysis was defined by applying the chosen earthquakes and ground motion records, and damping ratio was set as $5 \%$.

Table 3 Ground motion excitations chosen for the study

\begin{tabular}{ccccccc}
\hline Earthquake & Date & Magnitude & $\begin{array}{c}\text { PGA /raw } \\
\left(\mathbf{c m} / \mathbf{s}^{\mathbf{2}}\right)\end{array}$ & $\begin{array}{c}\text { PGA /scaled } \\
\left(\mathbf{c m} / \mathbf{s}^{\mathbf{2}}\right)\end{array}$ & Station & Direction \\
\hline $\begin{array}{c}\text { Imperial Valley } \\
\text { (USA) }\end{array}$ & $15 / 10 / 1979$ & $6.4 \mathrm{M}_{\mathrm{W}}$ & 309.1 & 419.0 & USGS Station, 5115 & -- \\
\hline $\begin{array}{c}\text { Koceali } \\
\text { (Turkey) }\end{array}$ & $17 / 08 / 1999$ & $7.6 \mathrm{M}_{\mathrm{W}}$ & 374.5 & 376.0 & $\begin{array}{c}\text { Duzce Merkez } \\
\text { Meteoroloji St., 8101 }\end{array}$ & E-W \\
\hline $\begin{array}{c}\text { Iquique } \\
\text { (Chile) }\end{array}$ & $01 / 04 / 2014$ & $8.2 \mathrm{M}_{\mathrm{W}}$ & 355.7 & 396.7 & Chusmiza, Chile, 2346 & NN 360 \\
\hline
\end{tabular}

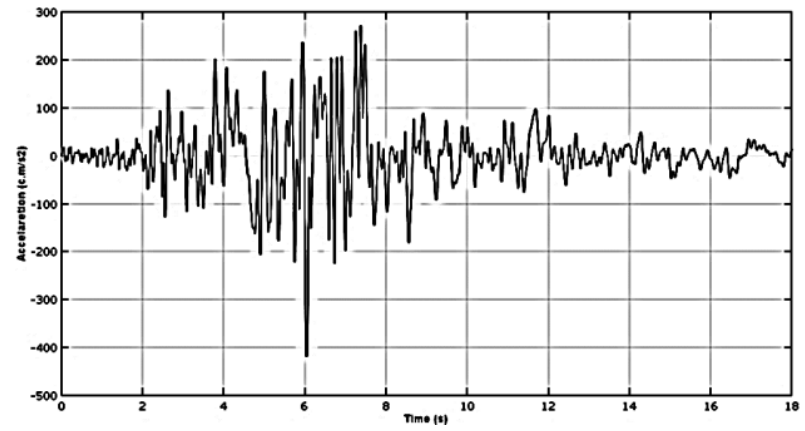

a) Imperial Valley 1979

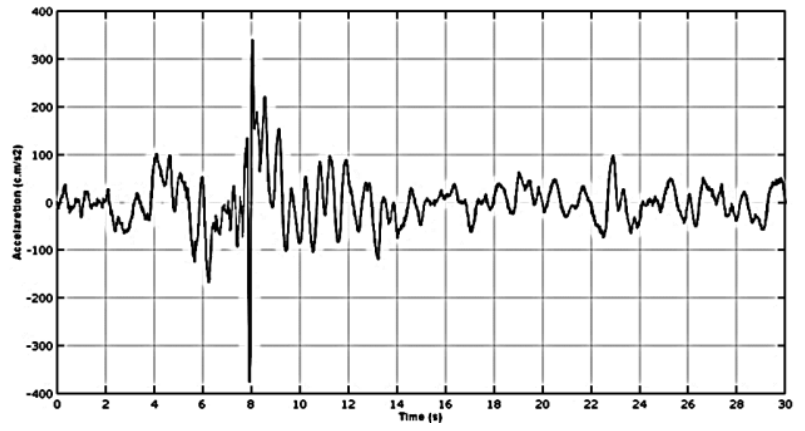

b) Koceali 1999

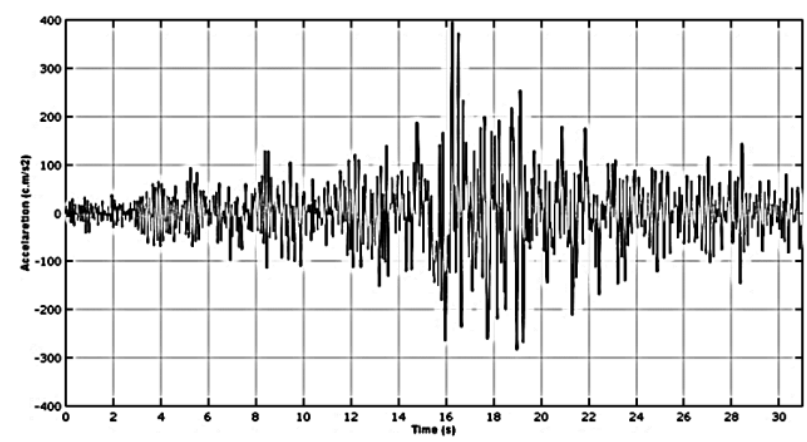

c) Chile 2014

Figure 6 Corrected and scaled earthquakes records used in this work

\section{Results}

Time history analysis and pushover analysis were carried out by applying a non-linear vertical loading (gravity loads compound of dead +0.3 live loads) followed by the ground excitation 
based on time steps for the time history analysis, or a gradually increasing displacement controlled lateral load for the pushover analysis. The loads were applied in both $\mathrm{X}$ and $\mathrm{Y}$ directions. The pushover curve which also known as capacity curve of the structure plots base shear versus displacement of the roof. From the pushover curve the maximum displacement at the roof and base reaction of the structure during displacement controlled analysis can be obtained.

The pushover curves for the building in-study when analyzed by displacement controlled analysis in both $\mathrm{X}$ and $\mathrm{Y}$ directions are shown in Figure 7. The capacity curves should give an indicator of the inelastic behavior of the structure and determine capacity limits. However, due to the limitations of SAP2000 in modeling plastic phenomena in shell elements, which used to model shear walls in the structure, the real plastic behavior of the total building could not be captured and the maximum base shear forces were not realistic. Although the tangent of the formed pushover curves shows the elastic capacity of the building and forms a reasonable envelop for the hysteresis under lateral loads.
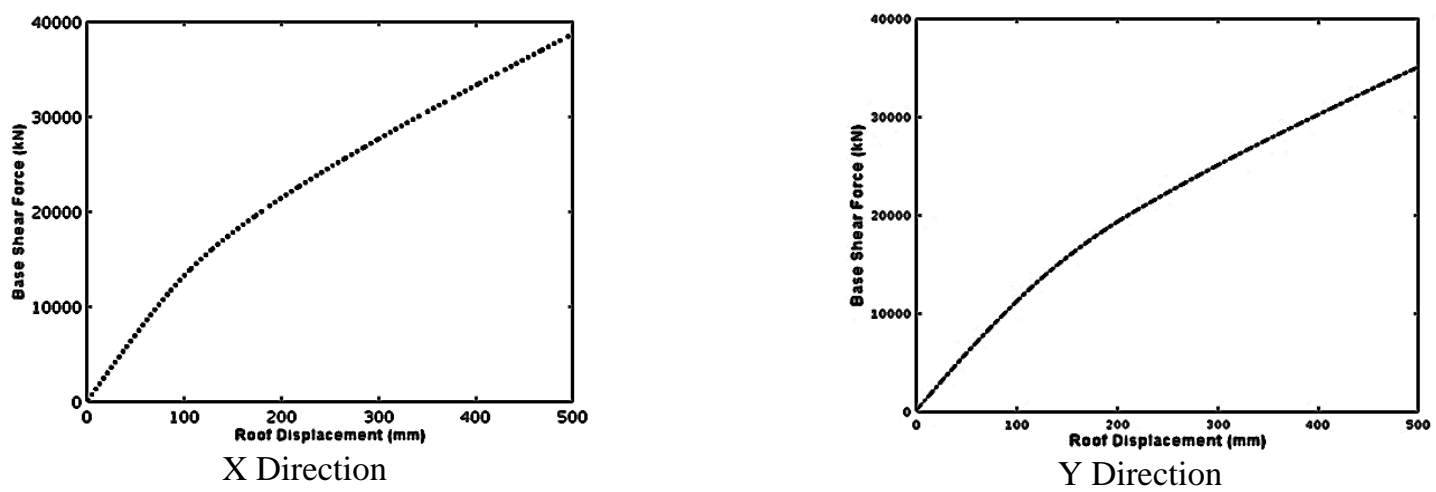

Figure 7 Pushover curves for the Studied Building

Total displacements from two opposite roof points, shown in Figure 5, were plotted against time and presented in Figure 8 to compare the three earthquakes excitations that were applied on the structure. Maximum values set in Table 4 and shows that Koceali's 1999 earthquake record which has the highest raw data PGA but not the highest scaled record has always the biggest displacements in X and Y directions. Moreover, these displacements show that Chiles's 2014 earthquake although it has the biggest magnitude but it always has the lowest displacements in all situations.

Table 4 Maximum Displacements for the two selected roof points, mm

\begin{tabular}{ccccc}
\hline & \multicolumn{2}{c}{$\mathbf{1}^{\text {st }}$ point } & \multicolumn{2}{c}{$\mathbf{2}^{\text {nd }}$ point } \\
\cline { 2 - 5 } & X dir. & Y dir. & X dir. & Y dir. \\
\hline Imperial Valley 1979 & 146.44 & 203.84 & 193.61 & 208.06 \\
\hline Koceali 1999 & 147.83 & 249.04 & 247.42 & 253.00 \\
\hline Chile 2014 & 130.25 & 199.95 & 184.50 & 203.64 \\
\hline
\end{tabular}


In conjunction with this, it can be noticed that the displacements in $\mathrm{Y}$ direction is somehow equal wherever it has been measured from, but on the other hand there is noticeable differences in displacements of the $\mathrm{X}$ direction, that is related to the way shear walls had been distributed across the building, where is on the Y directions there is a kind of symmetry while on $\mathrm{X}$ direction this symmetry is broken because of the walls of the elevator cores.

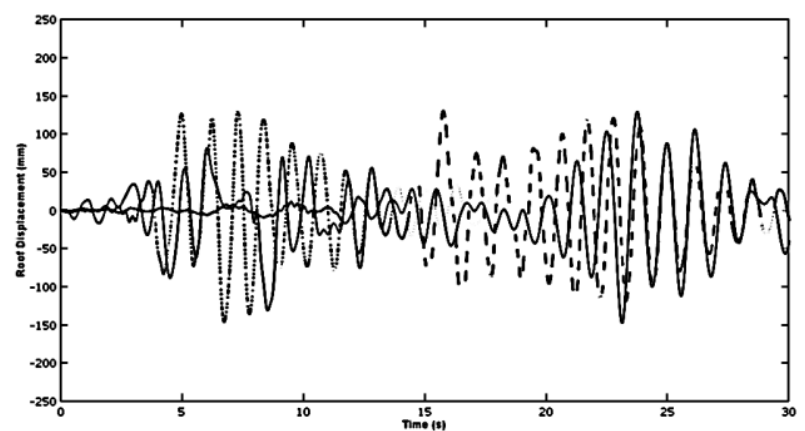

a) $1^{\text {st }}$ point in $\mathrm{X}$ dir.

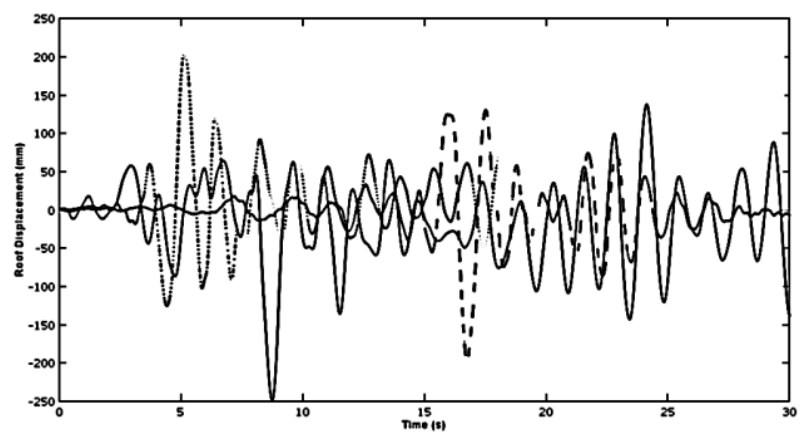

c) $1^{\text {st }}$ point in $\mathrm{Y}$ dir.

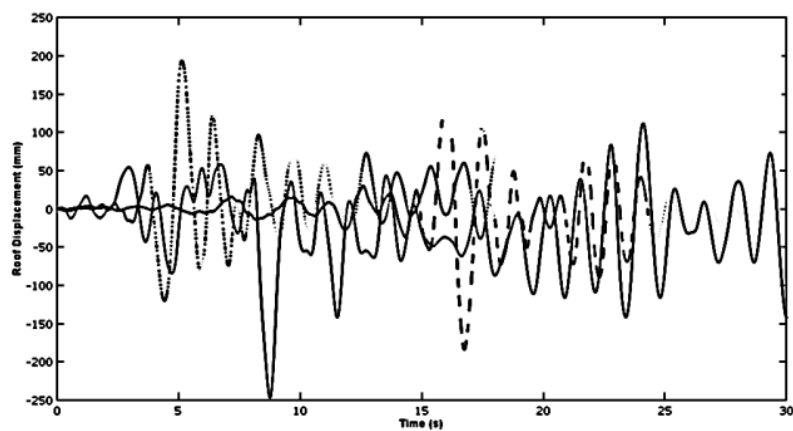

b) $2^{\text {nd }}$ point in $\mathrm{X}$ dir.

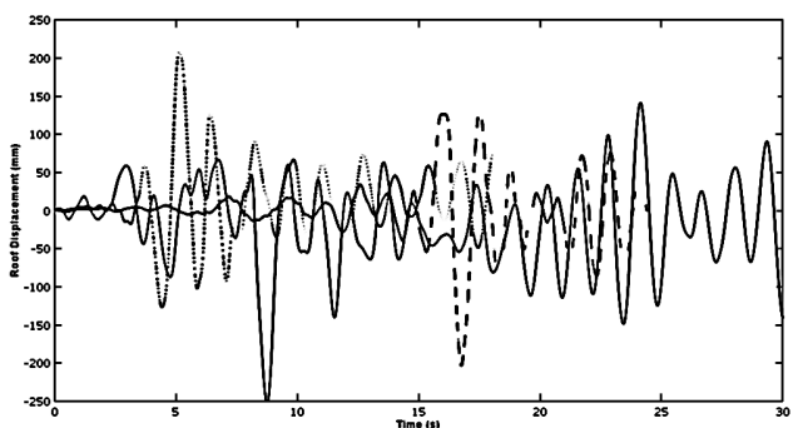

d) $2^{\text {nd }}$ point in $\mathrm{Y}$ dir.

Figure 8 Roof displacements vs. time for the two selected points in both directions

(---- Chile 2014, …. Imperial Valley 1979 and — Koceali 1999)
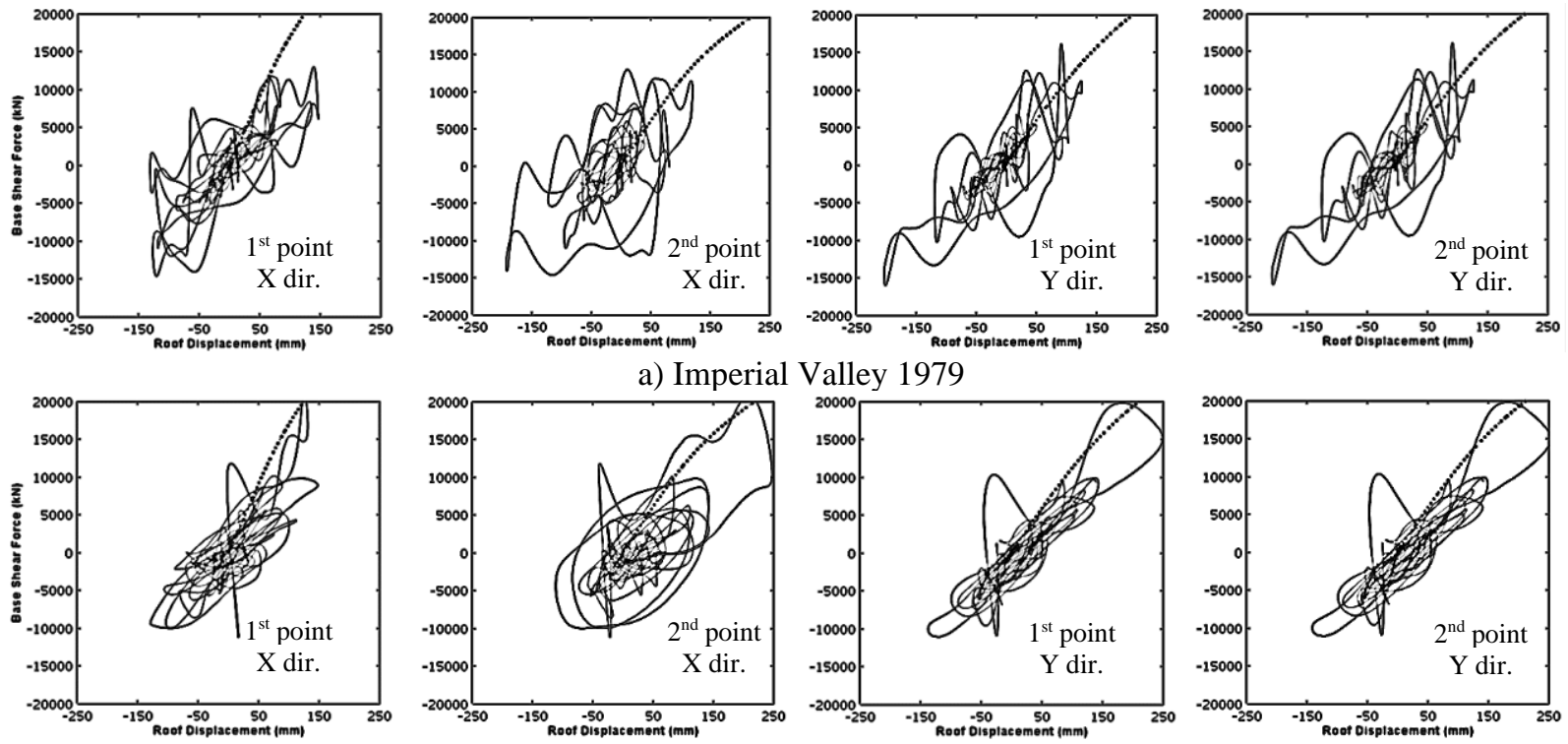

b) Koceali 1999 

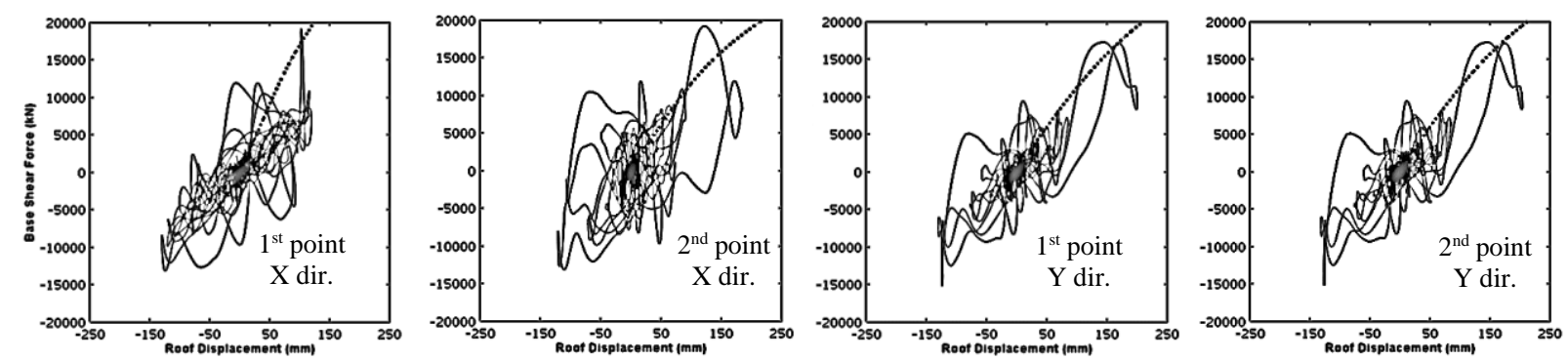

c) Chile 2014

Figure 9 Roof displacements vs. base shear force from Time history analysis

(…. Pushover curve, - Hysteresis)

\section{Conclusion}

Non-linear static (Pushover) and dynamic (Time history) analysis is an ideal method to explore the behavior and responses of reinforced concrete structures, although the right methods of modeling greatly affect the final results. For the building in this study and because the shear walls were modeled using shell elements which has limitation to model plastic hinges, the complete capacity of the building could not be determined. But the comparison between the applied hysteric loops and the capacity diagrams showed abilities of the system to withstand different types and magnitudes of ground motion in spite of old code dependencies and design methods. Also, the time history analysis shows over estimation in designing the load baring system which led to elastic like behavior of the system. In addition, the displacement diagrams, time series and hysteresis of different points in the roof showed the effects of the distribution of shear walls and the presence of cores in building plan onto the responses and behaviors of system.

\section{References}

[1] Daniel, D M and John, S T, "Pushover Analysis of RC Building", International Journal of Scientific \& Engineering Research, 7(10), 2016.

[2] Turkish Earthquake Code, "Specification for buildings to be built in earthquake regions", Ministry of Public Works and Settlement, Government of the Republic of Turkey, 2007.

[3] SAP2000 manual (Version 19.1), "CSI Analysis Reference Manual for SAP2000®, ETABS®, SAFE® and CSiBridge ${ }^{\circledR}$ ", Computers and Structures, Inc. Berkeley, USA, 2016.

[4] Mander, J B, Priestley, J N, and Park, R, "Theoretical stress-strain model for confined concrete", Journal of Structural Engineering, ASCE, 114 (8), 1804-1825, 1988.

[5] XTRACT, Cross Section Analysis Program for Structural Engineers, IMBSEN \& Associates Inc., USA, 2007.

[6] Ancheta, T D., Darragh, R B, Stewart, J P, Seyhan, E, Silva, W J, Chiou, B S J et al., "Peer NGAWest2 database", PEER Report, 2013.

[7] AFAD, Disaster and Emergency Management Presidency, Turkey "http://www.afad.gov.tr/".

[8] Fahjan, Y, "Türkiye Deprem Yönetmeliği (DBYBHY, 2007) Tasarım İvme Spektrumuna Uygun Gerçek Deprem Kayıtlarının Seçilmesi ve Ölçeklenmesi”, İMO Teknik Dergi, 19(93), 4423-4444, 2008.

[9] Rahman, M K, Ajmal, M, Baluch, M H and Celep, Z, "Nonlinear Static Pushover Analysis of an Eight Story RC Frame-Shear Wall Building in Saudi Arabia", 15. WCEE, Lisboa, 2012. 